\title{
SHOULD GIANTCELL ARTERITIS SIGNS BE DETECTED IN PATIENTS WITH HERPES ZOSTER?
}

\author{
Kulakli Fazil, ${ }^{1}$ Cayli Erdem, ${ }^{2}$ Kulakli Sevgi, ${ }^{3}$ Oguz Deniz Isil, ${ }^{3}$ \\ Celik Canan, ${ }^{1}$ Yildizgoren Turgut Mustafa ${ }^{4}$
}

\begin{abstract}
${ }^{1}$ Department of Physical Medicine and Rehabilitation, Giresun University Faculty of Medicine, Giresun, Turkey
${ }^{2}$ Department of Radiology, Giresun University Faculty of Medicine, Giresun, Turkey

${ }^{3}$ Department of dermatology, Giresun University Faculty of Medicine, Giresun, Turkey

${ }^{4}$ Department of Physical Medicine and Rehabilitation, Mustafa Kemal University Faculty of Medicine, Hatay, Turkey
\end{abstract}

Primljen/Received 10. 01. 2021. god.

Abstract: Objective: This study aims to determine the clinical, laboratory, and ultrasonographic findings of giant cell arteritis in patients with Herpes Zoster.

Methods: The study included 36 consecutive patients (median age 59.0 years; range 19 to 76 years) who were admitted to the Dermatology Outpatient Clinic with the diagnosis of Herpes Zoster. Demographic and clinical features of the patients were recorded. The presence of ultrasonographic characteristics of giant cell arteritis such as halo sign, compression sign, occlusion, and stenosis was also recorded using ultrasound. The patients were evaluated at baseline and 6 months.

Results: A total of 36 patients were assessed. 4 patients had jaw claudication (11.1\%), 5 patients had scalp tenderness (13.9\%), 11 patients had a new-onset headache $(30.6 \%)$ and, 23 patients had post-herpetic neuralgia (63.9\%). No patients had elevated erythrocyte sedimentation rate and ultrasonographic findings of Giant cell arteritis.

Conclusion: Our data show that a small proportion of patients with Herpes Zoster may have clinical findings suggesting Giant cell arteritis. However, they do not have elevated erythrocyte sedimentation rate and sonographic findings of Giant cell arteritis.

Keywords: Giant cell arteritis, Herpes zoster, Vasculitis.

\section{INTRODUCTION}

Varicella zoster virus (VZV) is a member of the Herpes viridae family and results in two different clinical conditions. VZV, also colloquially known as chickenpox, is the primary clinical outcome, charac-
Prihvaćen/Accepted 14. 02. 2021. god. terised by widespread exanthematous skin lesions. Shingles or herpes zoster (HZ) is a recurrent infection of latent VZV following the primary infection of the organism (1). HZ is diagnosed in $20-30 \%$ of healthy adults whereas this rate goes up to about $50 \%$ in immunosuppressed patients (2). Grouped vesicular lesions are seen on the innervated dermatome region of the ganglion (Generally thoracic-cervical dermatomes and the ophthalmic branch of the trigeminal nerve) where VZV is activated (3).

Giant cell arteritis (GCA) is a type of vasculitis diagnosed frequently in patients older than 50 years, which affects medium-to-large-sized arteries. It may produce a wide spectrum of clinical symptoms. New-onset headache is the most common symptom, followed by jaw claudication, vision problems, and scalp sensitivity (4). Diagnosis is usually made with clinical symptoms with additional diagnostic methods such as ultrasonography (USG) and other imaging techniques, laboratory parameters, and temporal artery biopsy. Temporal artery biopsy is considered the 'gold standardfor GCA (5). USG is also shown to have a higher sensitivity and specificity rate in GCA diagnosis when compared with biopsy and is proven to be much more cost-effective (6).

VZV complications include chronic pain (post-herpetic neuralgia), myelopathy, and vasculopathy. Vasculopathy is usually seen on cerebral arteries and might have negative outcomes such as transient ischemic attacks and stroke (7). VZV mostly reactivates in the elderly (the same age group in which GCA predominates), often affects arteries, and produces multinucleated giant cells in acutely infected tissue. 
In addition, VZV vaccines are reported to affect extracranial areas such as temporal, ophthalmic, and retinal arteries, which might cause GCA symptoms and results in some patients (8). In contrast, some studies report no sighting of VZV in the temporal artery and that VZV is not related to GCA etiology $(9,10)$. There is no study in the literature regarding whether there are any ultrasonographic changes on the temporal artery after HZ. Those opposing views found in the literature also cause more confusion about whether VZV plays a role in GCA etiology. Accordingly, this study aimsto determine the clinical, laboratory, and ultrasonographic findings of giant cell arteritis in patients with Herpes Zoster.

\section{MATERIAL AND METHODS}

36 consecutive patients over 18 -years who were admitted to the Dermatology Outpatient Clinic in Giresun University Faculty of Medicine with a diagnosis of Herpes Zoster (HZ) were enrolled between June 2019 - March 2020. Subjects with diseases that might affect vascular structures (vasculitis, hypertension, diabetes mellitus, etc.), severe infection, fever, cognitive dysfunction or mental retardation, multiple systemic diseases, malignancy, and open wounds were excluded. Demographic and clinical features of the patients including age, gender, comorbid diseases, current medications, varicella vaccination status, presence of symptoms associated with the temporal artery (such as jaw claudication, new-onset headache, vision problems, sensitivity in the temporal region) were recorded. The patients were evaluated at baseline and at 6 months.

Ethics approval for the study was obtained from the Ethics Committee of Giresun University (Date/No: 2018/117). Written informed consent was obtained from each subject. The study was conducted in accordance with the principles of the Declaration of Helsinki.

\section{Ultrasonographic Evaluation}

An ultrasound was performed by 10years experienced radiologist in vascular ultrasound using a Toshiba Aplio 500 Ultrasonography (Toshiba Medical System Corporation, Tokyo, Japan) a device with a high-frequency linear probe that supports doppler mode usage (PLT-1005 BT [4-14 MHz]). Colored Doppler frequency was set at $10 \mathrm{MHz}, \mathrm{PRF} 2-3 \mathrm{kHz}$, focus at $5 \mathrm{~mm}$ and depth was set at $1-2 \mathrm{~cm}$. Common superficial temporal arteries, their frontal and parietal branches were reviewed bilaterally on longitudinal and axial planes. The presence of GCA characteris- tics such as halo sign, compression sign, occlusion, and stenosis was recorded. Also, intima-media complex measurements, known to show higher values on vasculitis, were done using Schäfer VS et al's study as reference (11). The cut-off value for diameters in halo sign was set at $0.42 \mathrm{~mm}$ for superficial temporal artery, $0.34 \mathrm{~mm}$ for frontal branch, $0.29 \mathrm{~mm}$ for parietal branch, and $0.2 \mathrm{~mm}$ for intima-media complex thickness. "Compression sign" was defined as artery not being compressed when pressed with US probe, "occlusion" was defined as temporal artery filled with hypoechoic material despite decreased PRF and increased color gain setting, unable to get doppler signal, and finally "stenosis" was defined as the presence of turbulent colored patterns and persistent diastolic refill on Doppler USG with increased maximum systolic flow force on pulse-wave Doppler USG. Results were recorded as "positive" or "negative".

\section{Statistical analysis}

Data were analysed using the SPSS version 21.0 (SPSS, Inc., Chicago, IL, USA) program. Data were expressed as median (minimum-maximum) or $\mathrm{n}$ (percentage). The correlation between clinical variables was analysed with the Kolmogorov-Smirnov Test. Mann-Whitney U test was used to compare differences between the groups. Chi-square test and Fisher test were used to compare the differences between the groups. The significance level was set at $\mathrm{p}<0.05$.

\section{RESULTS}

Demographic, clinical, and ultrasonographic features of the subjects are given in Tables 1, 2, and 3 . None of the patients developed any signs of GCA. Although some patients described some symptoms given in Table 2 in detail, none of the patients showed GCA-specific findings. The mean value for intima-media complex thickness was found as $0.15 \pm 0.03 \mathrm{~mm}$ $(\min =0.10 \mathrm{~mm}, \max =0.19 \mathrm{~mm}$, median $=0.16 \mathrm{~mm})$. The mean Erythrocyte Sedimentation Rate (ESR) value of the patients was calculated as $24.75 \pm 10.86$ $\mathrm{mm} / \mathrm{h}$. Clinical features of the patients according to the

Table 1. Demographic features of the Herpes Zoster patients $(n=36)$

\begin{tabular}{|l|c|}
\hline Demographic features & $\boldsymbol{n}(\%)$ \\
\hline Age - years \\
\hline Median (min-max) & $59.0(19-76)$ \\
\hline Gender \\
\hline Female & $17(47.2)$ \\
\hline Male & $19(52.8)$ \\
\hline
\end{tabular}


Table 2: Clinical features of the Herpes Zoster patients $(n=36)$

\begin{tabular}{|l|c|}
\hline \multicolumn{1}{|c|}{ Clinical features } & n (\%) \\
\hline Jaw claudication & $4(11.1)$ \\
\hline Scalp tenderness & $5(13.9)$ \\
\hline New onset headache & $11(30.6)$ \\
\hline Vision problems & $2(5.6)$ \\
\hline Zostervaccinationstatus & 0 \\
\hline Drug usage \\
\hline Brivudin \\
\hline Valasiklovir & $22(66.1)$ \\
\hline Postherpetic neuralgia & $14(38.9)$ \\
\hline
\end{tabular}

Table 3: Ultrasonographic and Laboratory findings of the Herpes Zoster patients

\begin{tabular}{|l|c|c|}
\hline $\begin{array}{c}\text { Ultrasonographic } \\
\text { findings }\end{array}$ & Baseline & Followup \\
\hline Halo sign & - & - \\
\hline Compressionsign & - & - \\
\hline Stenosis & - & - \\
\hline Occlusion & - & - \\
\hline Laboratory findings & $24.75 \pm 10.86$ \\
\hline $\begin{array}{l}\text { Erythrocyte sedimentation rate, } \\
\text { mm/h }\end{array}$ & $3.2 \pm 0.4$ \\
\hline CRP, mg/L
\end{tabular}

Table 4. Clinical features of the Herpes Zoster patients according to the presence of post-herpetic neuralgia, $n(\%)$

\begin{tabular}{|l|c|c|c|}
\hline & PHN (-) $(\mathrm{n}=13)$ & PHN $(+)(\mathrm{n}=23)$ & P value \\
\hline Age, years & $57.0(19-68)$ & $65.0(19-76)$ & $\mathbf{0 . 0 1 8}$ \\
\hline Gender, Female/Male & $6(46.2) / 7(53.8)$ & $11(47.8) / 12(52.2)$ & 0.923 \\
\hline Jawclaudication & $1(7.7)$ & $3(13.0)$ & 1.000 \\
\hline Scalptenderness & $1(7.7)$ & $4(17.4)$ & 0.634 \\
\hline New onsetheadache & $4(30.8)$ & $7(30.4)$ & 1.000 \\
\hline Visionproblems & $1(7.7)$ & $1(1.3)$ & 1.000 \\
\hline
\end{tabular}

PHN: Post-HerpeticNeuralgia

presence of post-herpetic neuralgia (PNH) are shown in Table 4. There was no statistically significant difference between the groups, except age. Patients with post-herpetic neuralgia had older age.

\section{DISCUSSION}

There are various studies about the relationship between Varicella Zoster Virus (VZV) infections and Giant Cell Arteritis (GCA). In our study, none of the patients diagnosed with $\mathrm{HZ}$ showed clinical, laboratory, or ultrasonographic GCA signs both in baseline and follow-up, which might be interpreted as the absence of a relationship between HZ infections and GCA. However, we say further studies in this area are warranted due to the limitations mentioned below in detail.

Despite recent advances in immunology, GCA etiology is still unclear in the literature. Multiple environmental and genetic factors probably play a part in susceptibility to GCA. However, it is thought that the relationship between vascular walls and the immune system plays a role in the pathogenesis. Activated vascular dendritic cells gather CD4+ T-cells and macrophages towards the vessel wall $(12,13)$. Those cells then penetrate from the adventitia to the intima lay- er through vasa vasorum along with tissue space and this causes granuloma formation (12). As intracellular pathogens often cause a similar granulomatous inflammation response, infections are also thought to possibly trigger the same response in some of the patients (13). As HZ infections, which is one of the reasons thought to cause etiopathogenesis, are usually seen in elderly patients like GCA and cause a similar T-cell mediated immune response, it is thought that $\mathrm{HZ}$ and GCA show similar etiological properties. To elaborate this claim, VZV is known to cause vasculopathy, and the pathology samples from involved vessels are shown to contain multinucleated giant cells, similar to GCA (9). Previous studies have shown that a detailed review of temporal artery and aorta specimens of GCA patients with positive and negative biopsy results detected VZV antibodies and DNA in those samples. A recent case-control study showed no relationship between GCA and HZ, yet another case-control study reported an increased risk of GCA following $\mathrm{HZ}$ infections. $(10,14,15)$.

Another recently published case report described polymyalgia rheumatica, very similar to GCA symptoms and thought to be a part of the disease, in a patient with $\mathrm{HZ}$ infection (16). The curiosity sparked by those contradicting results reported in the literature drew us 
to conduct a study on whether GCA symptoms show up on $\mathrm{HZ}$ patients. In this direction, we assessed the presence of GCA symptoms in clinical, laboratory, and ultrasonography methods in those patients. Our study is a first in this regard which assessed this subject using USG. The main reason that we have chosen the USG review instead of temporal artery biopsy, which is the golden standard in GCA diagnosis, is due to the invasive nature and its association with high complication risks. In addition, it only assesses a part of a certain vein. Finally, ultrasonographic imaging was shown to have superior sensitivity and specificity for GCA diagnosis, not to overlook its cost-efficient nature (6). Ultrasonography can detect 4 characteristic pathologies in GCA. Those are thickening on the venous wall (halo sign), the artery cannot be compressed (compression sign), stenosis, and venous occlusion. Cellular infiltrates and edema can especially build up on intima and then spread out to media and adventitia layers in GCA. This thickening in the venous wall shows a hypoechoic image around the vein in USG and is named a "halo sign" $(17,18)$. The previous studies reported the cut-off value for halo sign diameter as 0.1-1 mm (19). Another recent study reported normal intima-media complex diameter in the temporal artery as $0.2 \mathrm{~mm}$ whereas those values increase up to $0.5-0.8$ $\mathrm{mm}$ in vasculitis (20). USG halo sign was reported to have a sensitivity of $55-100 \%$ and a specificity of 78 $100 \%$ in GCA diagnosis in a number of studies, yet this imaging method still did not replace temporal artery biopsy for GCA diagnosis (20). Temporal artery biopsy and colored doppler USG were compared prospectively in the TABUL study and sensitivity was reported as $39 \%$ to $54 \%$ and specificity was reported as $100 \%$ to $81 \%(21)$.

In our study, we used USG for the assessment of the temporal artery in $\mathrm{HZ}$ patients for the reasons stated above, however, this caused some limitations in the study. One of those limitations is that using the ultra- sonographic assessment method, although performed by an experienced radiologist, is still a debated method in definitive GCA diagnosis despite being widely used, secure and reliable today. Another limitation is that we did not perform temporal artery biopsy, which is the key point in diagnosis, in any of the patients. Yet this is because an invasive procedure like temporal artery biopsy is ethically unjustified in patients without any GCA clinical and/or laboratory results just for the diagnosis. Finally, our last limitation is the relatively short follow-up period of six months for the included patients in the study. There is a chance that those patients can develop GCA in the future and we might diagnose this during their routine follow-up. Even though the patients were assessed not only by USG but also with clinical and laboratory results for GCA-related symptoms, further studies with fewer limitations are required for this subject.

In conclusion, a small proportion of patients with HZ may have symptoms suggesting GCA. However, they do not have elevated ESR and sonographic findings of GCA. Clinical examination, laboratory, and US may help us to exclude a GCA diagnosis and thus to spare these patients from unnecessary immunosuppression.
Abbreviations
VZV - Varicella zoster virus
HZ - herpes zoster
GCA - Giant cell arteritis

Conflict of Interests: The authors declare that there are no conflicts of interest related to this article.

Funding: None

\section{Licensing}

This work is licensed under a Creative Commons Attribution 4.0 International (CC BY 4.0) License.

\title{
Sažetak
}

\section{DA LI BI ZNACI GIGANTOCELULARNOG ARTERITISA TREBALI BITI DETEKTOVANI KOD PACIJENATA KOJI IMAJU HERPES ZOSTER?}

\author{
Kulakli Fazil, ${ }^{1}$ Cayli Erdem, ${ }^{2}$ Kulakli Sevgi, ${ }^{3}$ Oguz Deniz Isil, ${ }^{3}$ Celik Canan, ${ }^{1}$ Yildizgoren Turgut Mustafa ${ }^{4}$ \\ ${ }^{1}$ Department of Physical Medicine and Rehabilitation, Giresun University Faculty of Medicine, Giresun, Turkey \\ ${ }^{2}$ Department of Radiology, Giresun University Faculty of Medicine, Giresun, Turkey \\ ${ }^{3}$ Department of dermatology, Giresun University Faculty of Medicine, Giresun, Turkey \\ ${ }^{4}$ Department of Physical Medicine and Rehabilitation, Mustafa Kemal University Faculty of Medicine, Hatay, Turkey
}

Cilj: Ova studija ima za cilj da utvrdi kliničke, laboratorijske i ultrasonografske nalaze gigantocelularnog arteritisa kod pacijenata sa herpes zosterom.
Metode: Studija je obuhvatila 36 pacijenata (srednja starost 59,0 godina; raspon od 19 do 76 godina) koji su primljeni u dermatološku ambulantu sa 
dijagnozom herpes zoster. Zabeležene su demografske i kliničke karakteristike pacijenata. Prisustvo ultrasonografskih karakteristika gigantocelularnog arteritisa kao što su halo znak, znak kompresije, okluzija i stenoza takođe je zabeleženo korišćenjem ultrazvuka. Pacijenti su ispitani na početku i nakon 6 meseci.

Rezultati: Pregledano je ukupno 36 pacijenata. Četiri pacijenta su imala klaudikaciju vilice $(11,1 \%), 5$ pacijenata je prijavilo osetljivost kože glave $(13,9 \%), 11$

\section{REFERENCES}

1. Mori I, Nishiyama Y. Herpes simplex virus and varicella zoster virus: why do these human alpha herpes viruses behave differently from one another? Rev Med Virol. 2005; 15(6): 393-406. doi: 10.1002/rmv.478.

2. Schmader K.Herpes Zoster. Clin Geriatr Med. 2016; 32(3): 539-53. doi: 10.1016/j.cger.2016.02.011.

3. Sterling JC. Viral infections. In: Burns T, Breathnach S, Cox N, Griffiths C, editors. Rook's Text Book of Dermatology. 8th ed. Oxford: Wiley-Blackwell; 2010. pp. 33.22-8.

4. Keser G, Aksu K. Diagnosis and differential diagnosis of large-vessel vasculitides. Rheumatol. Int. 2019; 39(2): 16985. doi: 10.1007/s00296-018-4157-3.

5. Banerjee PJ, Petrou P, Plant GT. Diagnostic and treatment challenges in giant cell arteritis. Lancet. 2014; 383(9936): 2210. doi: 10.1016/S0140-6736(14)61081-3.

6. Diamantopoulos AP, Haugeberg G, Hetland H, Soldal DM, Bie R, Myklebust G. Diagnostic value of color Doppler ultrasonography of temporal arteries and large vessels in giant cell arteritis: a consecutive case series. Arthritis Care Res. 2014; 66(1): 113-9. doi: 10.1002/acr.22178.

7. Gilden D, Cohrs RJ, Mahalingam R, Nagel MA. Varicella zoster virus vasculopathies: diverse clinical manifestations, laboratory features, pathogenesis, and treatment. Lancet Neurol. 2009; 8(8): 731-40. doi: 10.1016/S1474-4422(09)70134-6.

8. Gilden D. Association of varicella zoster virus with Giant Cell Arteritis. Monoclon Antib Immunodiagn Immunother. 2014; 33(3): 168-72. doi: 10.1089/mab.2014.0020.

9. Nordborg C, Nordborg E, Petursdottir V, LaGuardia J, Mahalingam R, Wellish M, et al. Search for varicella zoster virus in giant cell arteritis. Ann Neurol. 1998; 44(3): 413-4. doi: 10.1002/ana.410440323.

10. Kennedy PGE, Grinfeld E, Esiri MM. Absence of detection of varicella-zoster virus DNA in temporal artery biopsies obtained from patients with giant cell arteritis. J Neurol Sci. 2003; 215(1-2): 27-9. doi: 10.1016/s0022-510x(03)00167-9.

11. Schäfer VS, Juche A, Ramiro S, Krause A, Schmidt WA. Ultrasound cut-off values for intima-media thickness of temporal, facial and axillary arteries in giant cell arteritis. pacijenata je imalo novonastalu glavobolju (30,6\%), a 23 pacijenta postherpetičnu neuralgiju $(63,9 \%)$. Nijedan pacijent nije imao povišenu stopu sedimentacije eritrocita niti ultrasonografski nalaz gigantocelularnog arteritisa.

Zaključak: Naši podaci pokazuju da mali deo pacijenata sa herpes zosterom mogu imati kliničke nalaze koji ukazuju na gigantocelularni arteritis. Međutim, oni nemaju povišenu stopu sedimentacije eritrocita i sonografske nalaze gigantocelularni arteritisa.

Rheumatology (Oxford). 2017; 56(9): 1479-83. doi: 10.1093/ rheumatology/kex 143

12. Patil P, Karia N, Jain S, Dasgupta B. Giant cell arteritis: a review. Eye Brain. 2013; 5:23-33. doi: 10.2147/EB.S21825.

13. Hilhorst M, Shirai T, Berry G, Goronzy JJ, Weyand CM. T cell-macrophage interactions and granuloma formation in vasculitis. Front Immunol. 2014; 5: 432. doi: 10.3389/fimmu.2014.00432.

14. Gilden D, White T, Khmeleva N, Heintzman A, Choe A, Boyer PJ, et al. Prevalence and distribution of VZV in temporal arteries of patients with giant cell arteritis. Neurology. 2015; 84(19): 1948-55. doi: 10.1212/WNL.0000000000001409.

15. Nagel MA, White T, Khmeleva N, Rempel A, Boyer PJ, Bennett JL, et al. Analysis of Varicella-Zoster Virus in Temporal Arteries Biopsy Positive and Negative for Giant Cell Arteritis. JAMA Neurol. 2015; 72(11): 1281-7. doi: 10.1001/ jamaneurol.2015.2101.

16. Kulakli F, Kulakli S, Ilhanli I, Aslan A, Uysal E, Celik C. Polymyalgia rheumatica after herpes-zoster. Arch Rheumatol. 2018; 33(4): 494-5. doi: 10.5606/ArchRheumatol.2018.6859.

17. Schmidt WA. Role of ultrasound in the understanding and management of vasculitis. Ther Adv Musculoskelet Dis. 2014; 6(2): 39-47. doi: 10.1177/1759720X13512256.

18. Schmidt WA, Kraft HE, Volker L, Vorpahl K, Gromnica-Ihle EJ. Colour doppler sonography to diagnose temporal arteritis. Lancet. 1995; 345(8953): 866. doi: 10.1016/s01406736(95)93005-1.

19. Schmidt WA. Ultrasound in the diagnosis and management of giant cell arteritis. Rheumatology. 2018; 57(suppl 2): 22-31.doi: 10.1093/rheumatology/kex461.

20. Buttgereit F, Dejaco C, Matteson EL, Dasgupta B. Polymyalgia rheumatica and giant cell arteritis: a systematic review. JAMA 2016; 315(22): 2442-58. doi: 10.1001/jama.2016.5444.

21. Luqmani R, Lee E, Singh S, Gillett M, Schmidt WA, Bradburn $\mathrm{M}$, et al. The role of ultrasound compared to biopsy of temporal arteries in the diagnosis and treatment of giant cell arteritis (TABUL): a diagnostic accuracy and cost-effectivenes sstudy. Health Technol Assess. 2016; 20(90): 1-238. doi: 10.3310/hta20900.

\section{Correspondence to/Autor za korespondenciju}

Kulakli Fazil

Giresun University, Faculty of Medicine, Department of Physical Medicine and Rehabilitation

Phone: +904543102020

Email:drfzl46@gmail.com 